\title{
LETTER:
}

\section{CAVERNA DAS MÃOS: AN EXAMPLE OF DARK ZONE ROCK ART IN BRAZIL}

UDC: $551.44: 903.27(81)$

\author{
Luiz Eduardo Panisset TRAVASSOS ${ }^{1}$, Bruno Durão RODRIGUES ${ }^{2} \&$ \\ Aécio Rodrigo SCHWERTZ DA MOTTA ${ }^{3}$
}

\section{INTRODUCTION}

The Amazônia Legal (Legal Amazon), in Brazil, is the focus of several researches ranging from soil, vegetation, and forest products studies to researches on the Amazon's fauna and flora. Except for studies on caves in the Carajas iron formations (Pará) and studies on Venezuelans Tepuis quartzite cavities, little has been published about the work done by speleologists in carbonate and sandstone cavities in the region.

Therefore, this study has intents of being an academic record of the Caverna das Mãos. Local dwellers already knew the cave, mainly due to the dedication of Mrs. Erismar de Souza Silva, who, for decades, has visited such natural underground cavities. From 2011, Motta, a member of the Sociedade Brasileira de Espeleologia (SBE-Brazilian Society of Speleology) began systematically recording these findings.
Until the end of this work, the Brazilian national cave record by SBE reached 616 cavities. Among these, 72 were documented by Motta in the municipality of Rurópolis, and only 6 contemplated significant rock art records. Thus, field missions aimed at identifying and documenting cave painting in six sandstone caves, as follows: Caverna Jatobá (PA-326), Caverna das Mãos (PA329), Caverna Borboleta Azul (PA-332), Caverna Fernanda Caroline (cave of the 110/PA-336), Caverna Caximbão (PA-431), and Caverna das Damas (PA-466). Even with this exploratory study of the caves, one might argue that the sites visited have different characteristics from those reported by Pereira (2003) being, at first, the only ones in the region. The Caverna das Mãos shall be highlighted for its cave paintings in the aphotic zone, which is rare, if not the only one, in Brazil.

\section{STUDY AREA}

The caves are located within the boundaries of the municipality of Rurópolis, near the municipalities of Aveiro and Itaiatuba in the state of Pará. According to Vasquez et al. (2008), the regional geology is represented by Pale- ozoic rocks covered by areas of dense rainforest. On a local scale, in general, the region shows sandstone, shale, and siltstone. Access to the study field goes from Belém towards Santarém, then, either by air, land or river, to

\footnotetext{
${ }^{1}$ Geographer, Doctor in Karstology, Professor at the Graduate Program in Geography, PUC Minas, Brazil

${ }^{2}$ Geographer, Doctorate Student at the Graduate Program in Geography, PUC Minas, Brazil. Scholarship provided by CAPES

${ }^{3}$ Specialist in Environmental Management and Education from ESEA/TO, Brazilian Spelological Society \#1703

Received/Prejeto: 7.6.2012
} 
Itaituba. Set in the Amazon basin, the main regional drainage is the Tapajós River, tributary of the right bank of the Amazon River. Starting from Itaituba, access to the cavity is made by taking Transamazônica Road, and, obviously, through some portions on foot in the forest (Fig.1).

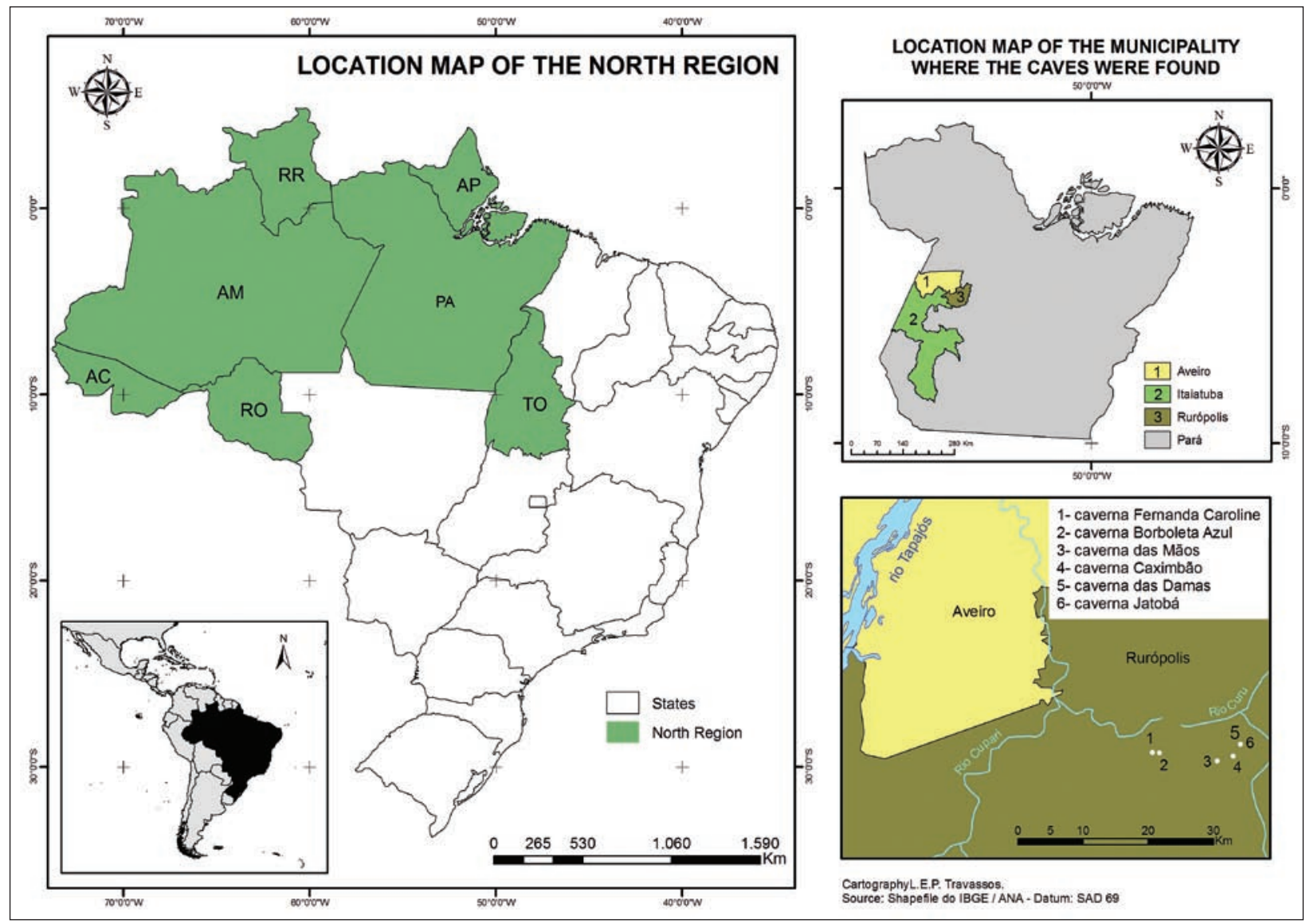

Fig. 1: Cave and study area location map.

\section{REGIONAL SIMPLIFIED GEOLOGY}

According to Costa and Hasui (1997), the geological history of the Amazon basin is characterized by different lithological and structural units caused by different processes resulting from thermotectonic events. It is also related to extensive depositional phases, which developed from the Archean to the Holocene, during approximately $3.2 \mathrm{Ga}$.

The study field for this paper is located between the municipalities of Itaituba and Rurópolis, in west Pará. Considering the Amazon river, the field is located on land drains to its right bank, having Tapajós River as regional drainage.

Geologically, the field is located in the tectonic domain of Amazonas Province near the boundary with Tapajós-Parima Province, located at the southern border of the Amazonian Craton. Considering due proportions, the region summarizes Amazon's geological history with its lithology dating from $2 \mathrm{Ga}$, exemplify by the undifferentiated granites found nearby Rurópolis and in the proximities of Transamazônica Road. They consist of continental basement rocks. It is also noteworthy that lithological layers originated in Paleoproterozoic are the rocks from the Iriri Group formed from the intense intra-continental magmatism occurred between 1.9 and $1.8 \mathrm{Ga}$. Composed of rhyolites, dacites in lava flow, and gold deposits, the Salustiano Formation (PP3 sa) is a highlight (Vasquez et al. 2008). Due to these gold deposits Faraco et al. (1997) prepared the Metallogenic Charter of the Tapajós Gold Province. 
The rock formation in the area over which the caves are found is a result of sediment deposition. In general, according to Vasquez et al. (2008), the region is covered by sedimentary rocks formed between the Devonian and the Cretaceous period (416 to 65 million years) having their genesis linked to fluvial-lacustrine, fluvial-deltaic, fluvial-aeolian processes, as well as to marine, glacial, tidal flats, and fluvial-deltaic environments. The most common lithological events are the sandstones, shales, siltstones, limestone lenses, evaporites, pelites, and conglomerates. The Groups Urupadi (D2e and D2mi), Cu- ruá (D3c1c), Tapajós (C2i and C2 no), and Javari (K2E1 ac) constitute the sedimentary package. In particular shales, siltstones, and sandstones of Urupadi Group, originated from fluvial-deltaic sedimentary processes (Vasquez et al. 2008) and having Ererê (D2e) and Maecuru as significant Formations. The latter with Lontra Member (D2ml) is where the caves, object of this study, are located. Finally, Holocene alluvial deposits (N4a) are located on the banks of the Tapajós River and at the base of the fluvial island of this same river, between the municipalities of Itaituba and Aveiro.

\section{GEOMORPHOLOGY, PHYTOGEOGRAPHY, AND LAND USE}

According to data provided by the project RADAM (1975), Folha Tapajós SB-21, the region where sandstone caves are located is under the Amazon Low Plateau domain, within subunit Middle Amazon Low Plateau. The dominant feature is flat-top dissected hill resulting from pediplen processes from the Pleistocene (Ventura et al. 1975, 134).

The derivative forms of geomorphology are covered by dense tropical forest formations, which are also synonymously called Dense Ombrophilous Forest (Tereso et al. 1975, 307). The Dense Ombrophilous Forest in the area where the cavities are located, according to Nimer (1979), is in the Tropical Hot weather domain; humid, with one annual dry season ranging from 2 to 3 months. The average annual temperature is above $20^{\circ} \mathrm{C}$ and the annual precipitation is around $1754 \mathrm{~mm}$ in the Itaituba town (Tereso et al. 1975, 320-321).

In the Dense Ombrophilous Forest domain, and particularly in the region where the cavities are located, ecosystem changes occur as defined by Tereso et al. (1975) as the Lower Montane Ombrophilous Forest described as having a low forest cover (compared to other ecosystem changes) with the canopy ranging from 10 to 25 meters tall (Tereso et al. 1975, 306).

Concerning the use of land, Lower Montane Ombrophilous Forest have been giving space to extensive livestock and to vegetable extraction, especially in the lower watershed areas. The upper and middle watersheds, in general, are still preserved; they are location sites of the cavities.

\section{THE CAVES AND THEIR ROCK ART REPRESENTATIONS}

Throughout the history of humankind, since the beginnings of humans, caves have played an important role in protection against bad weather. As they sought for shelter, many groups of human beings left records of their occupation in the form of archaeological remains such as lithic material, ash from bonfires, bones, paintings, graphics, and other cave paintings.

To Bahn (2004a), although most of the prehistoric cave art occurs in shallow, illuminated rock shelters, it is possible to argue there are also important world collections found in aphotic areas, inside the caves. The author numbers various caves in Europe where there are paintings dating from the Ice Age, in Eurasia. In Norway, for example, paintings were found within several caves dating from approximately 3000 years ago.
Such phenomenon is not exclusive to Europe; various caves in Australia, Tasmania, New Guinea, Borneo, China, and North America have a plethora of art within the cavities and not only in the euphotic and disphotic zones. To Bahn (2004a), since caves are usually seen as threatening and mysterious places, the public, in general, considers it to be magical, esoteric, secret, and ritualistic. Because many of these records were made at sites more "opened," such as rock shelters or walls with constant incidence of light, paintings done in total darkness of the caves are considered more "important" for they were made in privacy, as Bahn argues (2004a). In addition, we point out it must have been necessary to make artificial light by using fire.

International literature says the Mayas used caves for rituals, which were often conducted after long jour- 
neys inwards. To Bahn (2004a), total darkness, total silence, loss of sense of direction, changes in temperature, and claustrophobia could be the reasons which led primitive men to the interior of these spaces to express themselves or carry out their rituals.

According to Bednarik (2004), the study of cave art in European caves officially started in 1879 with the discovery of Paleolithic art in Altamira, Spain. Since then, other studies have been conducted. Nevertheless, it is known records of its existence are not recent. In 1458, Pope Callixtus III, had decreed that the religious ceremonies performed in the "Spanish cave with paintings of horses" would have to end. Therefore, these paintings were already known in the Middle Ages; however, not scientifically. Bahn (2004b) states, in Europe, many paintings were found in places less "public" denoting they were made for religious or ritualistic purposes, since they are linked to a complex mythology, thus not being possible to decipher them through a single explanation.

Regarding the depth in which paintings were made in South America, Stone (2004) argues the earliest ex- amples are in 32 to 67 feet sandstone rock shelters and no literature contemplates paintings in aphotic zone or in total darkness of the caves. Even the Cueva de las Manos, in Argentine Patagonia, has paintings dating from about 7,000 years and made in an area illuminated by natural light. Also according to Stone (2004), concerning the Americas, only in North America (Tennessee and Kentucky) cave paintings dating from 1,600 to 1,000 and in the aphotic zone were found. The collections of cave paintings were made in mud or wall sediment, and as incisions in the rock, like the caverns studied in Pará.

An important record of cave paintings made in dark zones, in Brazil, was made by Leite (1990; 1992). It is noteworthy that in her studies the author asserts that, in "panel VIII," figures can only be seen clearly when "a bright light is focused on them" (Leite 1992, 433-434). This leads us to believe such graphics were not made in total darkness or aphotic zone, like the Caverna das Mãos, in which the hands are painted 350 meters from the entrance.

\section{THE CAVERNA DAS MÃOS}

Studies about cave art in Amazon have been conducted since the first travelers went there centuries ago, as Prous (1993) highlights. Thus confirms Pereira (2003; 2006) talking about chronicles and reports by travelers and missionaries who arrived there in the beginning of the colonial years. Pereira (2006) points out historical observations in Amazon dating from 1656 and which were conducted by Father John de Sotto Maior. According to the author, this record is perhaps the second oldest in

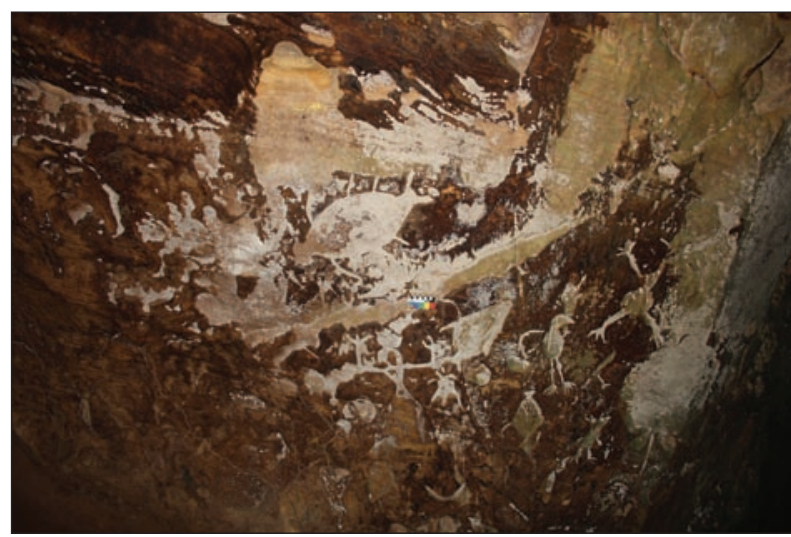

Fig. 2: Overall view of the first panel in the second entrance to the Caverna das Mãos. Notice the $10 \mathrm{~cm}$ IFRAO scale in the center. Twilight zone (Photo: L. E. P. Travassos).
Brazil and the first in the north region of the country regarding cave art.

The Caverna das Mãos, is obviously thus named for there are hands printed on the walls. Located on the km-120 of Transamazônica Road, towards Itaituba/Rurópolis it is perhaps the most important cave in the area. Located $4^{\circ} 09^{\prime} 22.78^{\prime \prime} \mathrm{S}$ and $55^{\circ} 04^{\prime} 17.05^{\prime \prime} \mathrm{W}$, it is developed on about 800 meters of sandstones of the Maecuru Formation, Lontra Member (D2ml).

The cave has two entrances, a major one and one on a lower level. In this secondary entrance it is possible to identify two panels with cave paintings facing each other, both in disphotic zones. They do not have similar styles nor tradition; therefore it can be inferred they have been made at different periods of occupation of the cave. The patterns in the panels depict a profusion of zoomorphic figures which may be related to birds, reptiles, fish, and even a mammal, perhaps a manatee (Fig. 2).

Through the other entrance to the cave, following a small stream for about 350 meters, it is possible to identify cave paintings with hands as positive forms on the walls. The importance of the cave, besides its geological features and the collection of paintings itself, is enhanced by the fact that the images were painted in aphotic zone, with no natural light, at all. One can 

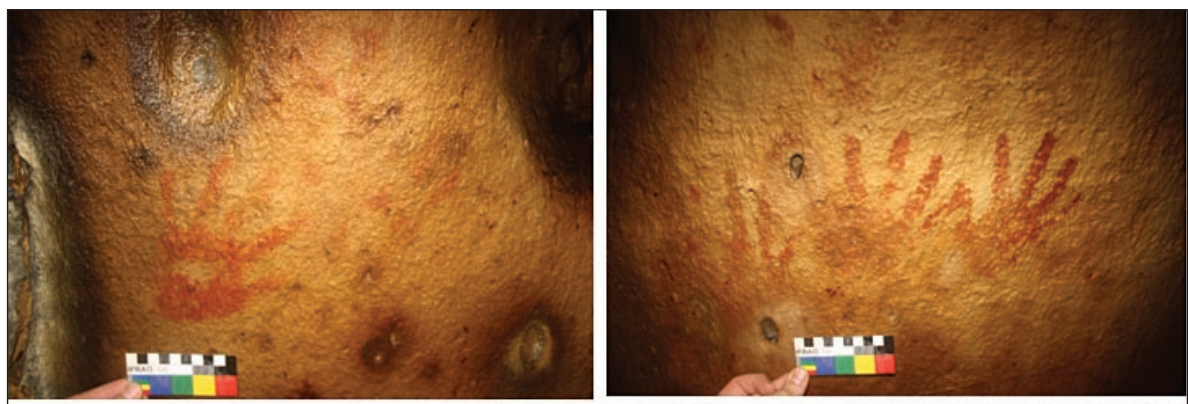

surmise a person or a group should dominate fire and know how to handle it inside (Fig. 3). The path to the panels sometimes follows meandering passages and sections with low ceiling.

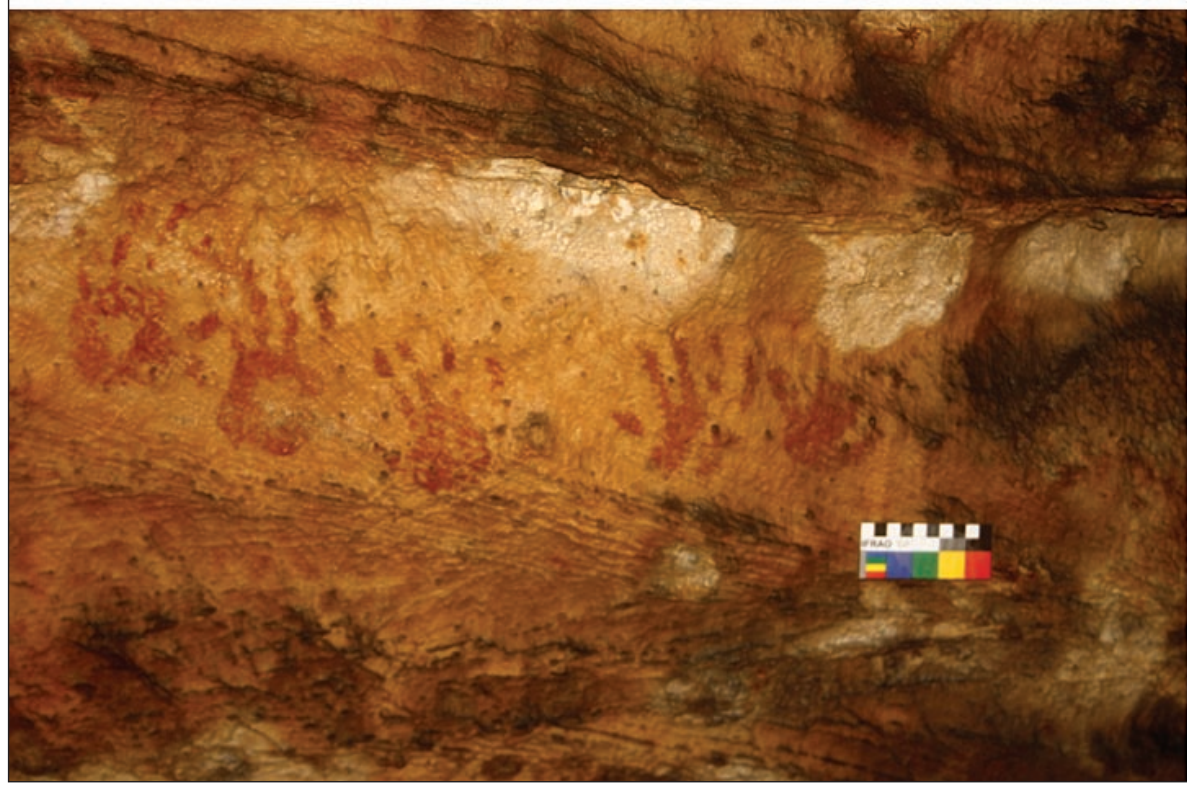

Fig. 3: Detail of hands as positive form. To get to this panel you must go through a short section with low ceiling; about $90 \mathrm{~cm}$. The paintings are about $90 \mathrm{~cm}$ from the ground (Photo: L. E. P. Travassos).

\section{FINAL CONSIDERATIONS}

For Pallestrini and Morais (1980), while conducting a serious study on cave art, in Brazil, it is necessary that the researcher or group observes panels inside, thus identifying the type of painting, its partition and scenes, positions, identifiable signs, and how many there are and if they are outlined. The overall vision is needed because, according to the authors, only the "entire collection might shed light to the symbolism intended with the painting" (Pallestrini \& Morais 1980, 34).
Therefore, it is desirable that archaeologists, especially those at the Museu Paraense Emílio Goeldi, intensify their studies on the region in partnership with speleologists, geographers, and geologists. It should also be noted that the authors of this paper are, first of all, speleologists and geographers, which limits the possibility of presenting further proposals beyond site identification and preliminary description, for future studies.

\section{REFERENCES}

Bahn, P.G., 2004a: Art in caves.- In: Gunn, J. (ed.). Encyclopedia of Caves and Karst Science. Fitzroy Dearborn, pp. 83-84, New York/London.
Bahn, P.G., 2004b: Art: Cave art in Europe.- In: Gunn, J. (ed.). Encyclopedia of Caves and Karst Science. Fitzroy Dearborn, pp. 90-91, New York/London. 
Bednarik, R., 2004: Art in caves: History. - In: Gunn, J. (ed.). Encyclopedia of Caves and Karst Science. Fitzroy Dearborn, pp. 85, New York/London.

Costa, J. B. S \& Y. Hasui, 1997: Evolução Geológica da Amazônia.- In: Costa, M. L. \& R. S. Angélica (eds.). Contribuições à Geologia da Amazônia. SBG - Sociedade Brasileira de Geologia, pp. 15-90, Belém.

Faraco, M. T. L., J. M. A. Carvalho, E. L. Klein, 1997: Carta Metalogenética da Província Aurífera do Tapajós.- In: Costa, M. L. \& R. S. Angélica (eds.). Contribuições à Geologia da Amazônia. SBG - Sociedade Brasileira de Geologia, pp. 423-444, Belém.

Leite, N., 1992: Arte rupestre na gruta do Índio (MGJF 17).- In: Proceedings of the $3^{\text {rd }}$ Congresso $d a$ ABEQUA, Belo Horizonte, ABEQUA, 431-457, Belo Horizonte.

Leite, N., 1990: O estudo sistemático dos grafismos da Gruta do Índio (Januária-MG.) no contexto arqueológico regional. $\mathrm{PhD}$ thesis. University of São Paulo, pp. 248.

Pereira, E., 2003: Arte rupestre na Amazônia: Pará.Museu Paraense Emílio Goeldi/UNESP, pp. 245, Belém/São Paulo.

Pereira, E. S., 2006: Historia de la investigación sobre el arte rupestre en la Amazonía brasileña.- Revista de Arqueologia Americana, 24, 67-98.
Stone, A., 2004: Art: Cave art in the Americas. - In: Gunn, J. (ed.). Encyclopedia of Caves and Karst Science. Fitzroy Dearborn, pp. 91-93, New York/London.

Pallestrini, L. \& J. L. de Morais, 1980: Arqueologia préhistórica brasileira.- USP/Museu Paulista, São Paulo.

Prous, A., 1993: Arqueologia brasileira.- Brasília, UnB.

Tereso, E. F. M., L. Góes Filho, H. C. Ferreira, H. P. Veloso, W. N. Fonseca \& S. B. Silva., 1975: As Regiões Fitoecológicas, sua Natureza e seus Recursos Econômicos - Estudo Fitogeográfico.- In: PROJETO RADAM - Folha SB-21 Tapajós. DNPM Departamento Nacional de Produção Mineral, pp. 287-384, Belém.

Vasquez, M. L., C. S. Souza, J. M. A. Carvalho., 2008: Mapa Geológico e de Recursos Minerais do Estado do Pará. Escala 1:1.000.000. Programa Geologia do Brasil (PGB), Integração, atualização e Difusão de Dados da Geologia do Brasil. Mapas Geológicos Estaduais. CPRM- Serviço Geológico do Brasil. Superintendência Regional de Belém.

Ventura, L. M.; L. M. D’Ávila \& G. V. Barbosa, 1975: Geomorfologia.- In: PROJETO RADAM - Folha SB-21 Tapajós. DNPM - Departamento Nacional de Produção Mineral, pp. 117-158, Rio de Janeiro. 